Japanese Research in Business History 2009 | 26

\title{
Japanese cotton spinning industry mergers and acquisitions during the Showa Depression: the case of Toyo Spinning Co., Ltd. and Osaka Godo Spinning Co., Ltd.
}

\author{
Kenta KATO
}

\section{INTRODUCTION}

7 He JaPAnese cotton spinning industry in the interwar period experienced a series of shocks, starting with the depression of 1 the 1920s, the Great Kanto Earthquake, financial crisis, and the Great Depression. Forced to adapt to intensifying international competition and macroeconomic instability in Japan, industry rationalization proceeded in a variety of forms. One of the main pillars of the economic policy of the Osachi Hamaguchi cabinet, which took office in July 1929, was the lifting of the embargo on the import and export of gold. At the same time, and as steps toward the goal of lifting the gold embargo, the Hamaguchi cabinet pushed forward an active industrial policy, including the establishment of the Extraordinary Industrial Council in January 1930, and the Ministry of Commerce and Industry Extraordinary Rationalization Bureau in June of the same year, as a result of which the movement for industry rationalization became more widespread. Streamlining management in the spinning industry ${ }^{1}$

1. Regarding rationalization of the spinning industry, see Hiroshi Nishikawa, “1920nendai no Nihon menshi bōsekigyō no 'gōrika' to dokusen taisei ['Rationalization' and monopolies in the 1920s Japanese spinning industry]," Tochi Seido Gakushi 62, 1974; Yutaka Taniguchi, "Showa shoki ni okeru honbō menbōsekigyō no gōrika katei 
focused primarily on the improvement of production technology and business administration, but was attempted additionally through "company external relations," namely "management cooperation through syndication" and "strengthening corporate management by corporate mergers.",

In this paper the case of Toyo Boseki Kabushiki Kaisha [Toyo Spinning Company, Limited] (hereafter Toyobo) and Osaka Godo Boseki Kabushiki Kaisha [Osaka Godo Spinning Company, Limited] (hereafter Godobo) is used to highlight (1) the motivations for mergers, (2) the fairness of merger terms, and (3) the effectiveness of the mergers that took place in the cotton spinning industry during the Showa Depression. For item two above, examining the minutes of Godobo shareholder general meetings, explanations of the company chairman, the opinions of the company auditor ${ }^{3}$ and the tenor of media opinion, I attempt an evaluation of the merger ratio calculation. For item three above, from the perspective of reallocation of management resources, I focus on the kind of investment provided for the plant of Godobo, the company being taken over.

First, a review of the existing research. As far as I can ascertain there has been very limited case study research of mergers in the inter-war spinning industry, and not just of the case of Toyobo and godobo. Toyobo, however, has been mentioned in the history of the spinning industry. For example, Manji Iijima (1949), discussing company consolidation at the time of the financial crisis, while urging rationalization of small- and medium-sized spinning companies, raises the case of Toyobo and Godobo, suggesting that "there were not a few cases of rationalization through consolidation."4 Mitsuhaya Kajinishi

[The process of rationalization of the early Showa domestic spinning industry]" Keizaigaku Kenkyū 26 (1983); Naosuke Takamura, "Shihon chikuseki [The Accumulation of Capital]," in Nihon Teikokushi 2 Sekai Daikyōkōki [History of Japanese Imperialism, Volume 2, The Great Depression], ed. Kaichiro Oishi (Tokyo: University of Tokyo Press, 1987).

2. Manji Iijima, Nihon Bōsekishi [The History of Japanese Spinning] (Tokyo: Sogensha, 1949), 237.

3. As is noted below, as there was no particular shareholder opposition to the merger conditions at the shareholder general meeting, shareholder interests were not considered in sufficient depth.

4. Iijima, Nihon Bōsekishi, 239. 
(1964), in relation to the formation of the "Big Five Spinners," while introducing the details of the merger between Toyobo and Godobo, argues that the cause of the merger was "due to a slump in business at Godobo" as a result of weak management and continued booked losses ever since the establishment of the company. ${ }^{5}$ However, while these studies touch on the direct causes of the merger, they do not include a consideration of the merger from the standpoint of business strategic aims and the conditions obtaining at the time.

In the 1930s, there were numerous large-scale mergers involving companies such as Oji Seishi and Nihon Seitetsu, ${ }^{6}$ among which can be counted the case of Toyobo and Godobo. In this paper, while bearing in mind ongoing rationalization of the cotton spinning industry and taking into account the merger impact, I use the discussion that occurred at the extraordinary general meeting of Godobo shareholders to examine the claims of the company chairman and the auditor concerning the merger in light of the calculation of the merger ratio.

The paper is structured as follows. Section two provides an overview of mergers in the cotton spinning industry in the inter-war period. Section three is devoted to a case study of the merger of Toyobo and Godobo. The conclusions are drawn up in section four.

\section{THE INTER-WAR COTTON SPINNING INDUSTRY: INDUSTRY}

\section{RATIONALIZATION AND MERGERS}

Kajinishi (1964) argues that the mergers and acquisitions of the interwar cotton spinning industry were characterized first by the "big six spinners" (Toyobo, Dainihonbo, Kanebo, Fujigasubo, Nisshinbo, Godobo) which accounted for the majority of acquisitions, while small and medium enterprises were their main targets; and second that merger conditions were disadvantageous to the takeover targets. ${ }^{7}$ Although we

5. Mitsuhaya Kajinishi (ed), Gendai Nihon Sangyō Hattatsu Shi [The History of Modern Japanese Industrial Development, Volume XI, Textiles, Part I] (Tokyo: Gendai Nihon Sangyō Hattatsu Shi Kenkyūkai, 1964), 422-424.

6. For example, Haruhito Takeda, "Shihon Chikuseki (3) Dokusen Shihon [The Accumulation of Capital (3) Monopoly Capital]," in Nihon Teikokushi 2 Sekai Daikyōkōki [History of Japanese Imperialism, Volume 2, The Great Depression], ed. Kaichiro Oishi (Tokyo: University of Tokyo Press, 1987), 224-233.

7. Kajinishi, Gendai Nihon Sangyō Hattatsu Shi, 422. 
have the means to verify the second point above, the histories of the companies concerned have already pointed out that M\&A activity in the 1920s spinning industry primarily targeted companies with weak management. For example, the 100 year history of the Toyo Company (1986) notes that in the early 1920s the number of new enterprises was much lower than the number planned during the World War I period, many of the new companies having been dissolved about when factories were to be established, and even at those companies that managed to begin operations, performance suffered in the depression from 1920 and "many were acquired or merged with existing spinning companies." ${ }^{8}$ As an example of this pattern, Imabari Spinning suffered a slump in business from around 1922 and approached Godobo, through the intermediary of mutual business partner Maruei. Godobo bought the entire plant and facilities of Imabari, which had paid-up capital of 2.25 million yen, for 760,000 yen. ${ }^{9}$ While such conditions are unfavorable to the acquired company, they can equally be explained by the poor management of small spinning companies and the corresponding decline in their bargaining power. However, the merger between Toyobo and Godobo reflected the changing business environment facing the cotton spinning industry and came to mark a clear break from the conditions of the 1920s.

From 1930, the Hamaguchi cabinet embarked earnestly on efforts to rationalize industry in preparation for the implementation of lifting the gold embargo. Corporate consolidation was one powerful tool to this end, advocated by both public and private sectors. The cotton spinning industry, had relatively early begun to streamline business as a measure in preparation for the abolition of night work; the coming gold embargo was a further stimulus encouraging rationalization. Textiles Association chairman and Toyobo company president Fusajiro Abe in early 1929, strongly urged the need to streamline and improve management efficiency, ${ }^{10}$ but these improvements proceeded mainly in areas related

8. Tōyō Bōseki Kabushiki Kaisha Shashi Henshūshitsu (ed.), Hyakunenshi Toyobo Jō [One hundred year history of the Toyobo Company Part I] (Osaka: Tōyō Boseki Kabushiki Kaisha, 1986), 244.

9. Tōyō Bōseki 70nenshi Henshū Iinkai, Toyo Bōseki 70nenshi [70-year history of Toyo Spinning] (Osaka: Tōyō Bōseki Kabushiki Kaisha, 1953), 259-260.

10. Fusajiro Abe, "Men Gyōkai no Zento [Prospects of the Cotton Industry]," Dai Nippon Bōseki Rengōkai Geppō, no. 436, December 1928. 
to production technology and management. Measures raised as means of improving production technology included "simplification of the prespinning process by implementation of high draft spinning, installation of vacuum dust removal equipment for carding, used-cotton synchroprocess, and the introduction of temperature and humidity control devices in the spinning room." Streamlining proceeded through the adoption of small-scale induction motors and a single system of operation, energy cost savings through reduced electricity tariffs, and increasing the automation and speed of weaving. Improvements in business management included "an increase in the operating speed of machinery, establishment of standard working practices, investment in machinery, equipment, and the implementation of product standardization." 11 At the same time, as an "industry rationalization movement to escape the recession, in addition to improvements in internal management, machinery and technology, relations with other companies should be considered. As a result, business cooperation through association appeared among some companies, and in other cases business management was strengthened by industry consolidation" 12 (emphasis added) was noted, and comments regarding industry rationalization and consolidation were noted.

At this time, however, the cotton spinning industry did not actively make use of mergers and consolidation as a means of industry rationalization. Towards the late $1920 \mathrm{~s}$, the number of mergers dropped markedly, without a single confirmed case in the years 1928 to 1930, 1932 and $1933 .{ }^{13}$ This was probably due to the advancement of spinning industry consolidation up to the mid 1920s, and the prioritization of internal streamlining, particularly among the big six spinners and major companies.

When the merger of Toyobo and Godobo was announced against this background, surprised comments noted that it "was sudden and unexpected" 14 and came "right out of the blue." 15 As a result of the

11. Kajinishi, Gendai Nihon Sangyō Hattatsu Shi, 446.

12. Iijima, Nihon Bōsekishi, 237.

13. Kajinishi, Gendai Nihon Sangyō Hattatsu Shi, 423-424; Osaka Yashōten Chōsabu, Kabushiki Nenkan [Stock Yearbook], 1933; ibid., 1934.

14. "Daitōyōbō no Naiyō [Details of Dai-Toyobo]," Tōyō Keizai Shinpō, 22 November 1930. 
merger of two companies, and while the merger of the major spinning companies was actively advocated by some, comments were aired in other quarters expressing concern about the impact on small businesses and raw cotton dealers. ${ }^{16}$ While real progress in consolidation of the spinning industry had to wait until wartime, the impact of the merger was by no means small. The reasons were as follows. First, the very large size of Godobo, the acquired company, compared to previous mergers. The paid-up capital of the company was 18.75 million yen, far surpassing the next-largest companies, Tokyo Calico Weaving, at 5 million yen, Kinka Textiles at 4.2 million yen, and Kagoshima Textiles at 3.92 million yen. ${ }^{17}$ Second, as well as company size, the management situation of the two companies differed from that of the mergers of the 1920s. In other words, "many mergers to date were implemented for the purpose of reorganization of poorly-performing companies, while this merger is of a completely different kind. Without doubt Toyobo, but no less Godobo, in these last couple of quarters have faced some losses due to the falling price of raw cotton and consequently released some poor results, yet both remain solid, first-class spinning companies," and was evaluated as a "merger of blue-chip companies."18 This paper focuses on the Toyobo-Godobo merger as an exceptional case that had an extremely large impact at the time.

\section{THE MERGER OF TOYOBO AND GODOBO}

1. Two major combination theories and their weaknesses

As mentioned above, the Japanese spinning industry, in addition to the national recession that followed on from the 1929 Great Depression, also faced a series of difficulties including an increased Indian tariff on cotton from 1930, the fall in the price of silver bullion, and lower raw cotton prices. Under these circumstances, from February 1930, the

15. "Chikagoro no Kessaku: Ni Daibōseki no Gappei [Recent Masterpieces: The merger of two major spinning companies]," Tōkyō Hinichi Shinbun, 9 November 1930.

16. Tōyō Gōdō Gappei no Hamon [Effects of the merger between Toyo and Godo], Kōbe Yūshin Nippō, 9 November 1930.

17. Kajinishi, Gendai Nihon Sangyō Hattatsu Shi, 423-424.

18. "Daitōyōbō no Naiyō [Details of Dai-Toyobo]," Tōyō Keizai Shinpō, 22 November 1930. 
Japan Cotton Spinning Federation implemented their 11th program of production curtailment, pressing forward at the company level with "thorough management and technical rationalization through integrated management for export production, and increased automation and faster operation throughout the weaving process." 19 From this context emerged the movement for business rationalization through consolidation. Below, I examine the explanation of Chairman Kazuji Iio at the 72nd General Meeting of Osaka Godo Spinning about a "Spinning Industry Consolidation Proposal," related to the proposed merger between Toyobo and Godobo, and for clues as to why the proposal did not proceed.

The program of production curtailment was not having sufficient effect on supply and demand to bring about a recovery in company earnings. Consequently, four or five companies held informal talks concerning measures to be taken in response to the recession in April 1930, at which time the spinning industry consolidation proposal appeared. ${ }^{20}$ We can deduce that the companies taking part in the meeting included Toyobo, Godobo, Izumi Spinning and Yoshimi Spinning. ${ }^{21}$

The members of this advisory council discussed measures to be taken against the depression, such as export promotion, sales regulation and wage reduction, but their differing positions meant that no useful ideas

19. Nihon Sen'i Kyōgikai (ed.) Nihon Sen'i Sangyōshi: Sōronhen [A History of the Japanese Textiles Industry: General volume] (Tokyo: Sen'i Nenkan Kankōkai, 1958), 4445.

20. Ōsaka Gōdō Bōseki Kabushiki Kaisha, Dai 72kai Kabunushi Sōkai Gijiroku [Minutes of the 72nd Shareholder's Annual General Meeting], 2 December 1930 (Tōyō Bōseki Shashi Shiryō [Toyo Spinning Company Historical Documents]). Below, "72nd shareholder's meeting minutes."

21. Izumi Spinning and Yoshimi Spinning were commonly regarded as affiliates of Godobo, but if one examines the 1929 primary shareholders and their shareholdings, Godobo's share of the former is President Ryōichi Uno (4.7 percent), the latter board director Toyosaburō Taniguchi (47.9 percent), so this does not appear to be true in the case of Izumi Spinning. Furthermore, at that time, a merger with Zaikabo (Dōkyō Bōseki and Yūhō Boseki) was also discussed (Tōyō Bōseki Kabushiki Kaisha Shashi Henshūshitsu (ed.), Tōyō Bōseki Shashi Shiryō 28 Katayama Renji Shi Dan "Gōdōbō no Gappei wo Kataru” [Toyo Spinning Company Historical Documents 28: Renji Katayama interview "The merger with Godobo"] (Osaka: Tōyō Bōseki Kabushiki Kaisha, 27 December 1949), (below, Katayama interview); Ōsaka Yashōten Chousabu, Kabushiki Nenkan [Stock Yearbook], 1930). 
came out of the meeting and left no other option still on the table other than a major merger. The talks ended with the conclusion that "if everyone participated in the discussion from the standpoint of mutual advantage, it is by no means impossible, but as it is not possible to discuss a solution from the standpoints of individual advantage, in this case the proposal to engage in large-scale mergers among each other should be considered" (emphasis added). ${ }^{22}$ On the basis of this conclusion, while each company embarked on a detailed examination of its financial health, in the end this merger proposal suffered a temporary setback and remained unimplemented. The chairman of Godobo highlighted the gap between stock and asset quality as the reason for this failure. That is, because "the stock price of a company with a slightly positive reputation is greatly overvalued with respect to the quality of the company's assets, while in contrast the stock price of a company with a slightly negative reputation is greatly undervalued with respect to the quality of the company's assets," it would likely be difficult to earn approval for mergers from shareholders who were focused on share price. ${ }^{23}$ Meanwhile, the Ekonomisuto (a Japanese economic magazine) reported a different proposal for consolidation. While the real motive of the article is not clear, the content is introduced here. First, if the five participating companies Toyobo, Godobo, Dainippon Spinners, Naigaimen and Fukushima were to merge, their market share would reach 30 percent of spinning machines and 46 percent of cotton yarn production. However, in addition to the asset valuation issues mentioned above, post-merger executive appointments were a bottleneck, in particular getting approval from members of the Nomura Zaibatsu who were represented in Fukushima, and consequently the "ideal plan" never saw the light of day. ${ }^{24}$

22. 72nd shareholder's meeting minutes.

23. 72nd shareholder's meeting minutes.

24. "Tōyō, Gōdō Ryōbōseki no Gappei [The Merger between Toyo and Godo Spinning Companies]," Ekonomisuto, 1 December 1930 (below, "Gappei”). Furthermore, the Osaka Asahi Shimbun speculated that, with the admission by President Iio of Godobo in spring 1930, other than Fukushima Spinning the four major spinning companies mentioned above had all admitted the existence of a merger plan, implying that there must have been some contact other than given in the explanation at the shareholders' general meeting ("Tōyō Gōdō no Gappei [The Merger between Toyobo and Godobo]," Ōsaka Mainichi Shimbun, 9 November 1930). 
As described above, the prehistory of the merger of Toyobo and Godobo included consideration of a major merger plan between four or five of the large spinning companies. While in the background to the failure of this plan there was probably a variety of interests, including those of management and shareholders, the principle direct obstacle was conflict over asset valuation. The problem of asset valuation, to put it another way, was a tug of war over merger terms; this continued to be a significant bone of contention when the parties involved were reduced to just two companies, Toyobo and Godobo. I shall return to this point in section three below, after first considering the motives for the merger.

\section{Merger motives}

In September 1930, four months after the derailing of the merger proposal involving the four spinning companies, the merger of Toyobo and Godobo was on the tracks. At the Godobo general meeting mentioned above, it was noted that "if we were to proceed with Toyobo alone, it would be possible to carry out an in-depth investigation, and we consider that it should not be difficult to carry out a merger." Godobo also proposed, regarding Toyobo, to carry out "an investigation predicated on the idea of a merger, or to put it another way, a conciliatory investigation taking each other's interests to be our common interest, to take on the other side's (Toyobo's) strengths as our own, and to show to them our strengths." From this, it is possible to see that Godobo was planning to reallocate the management resources of each company in order to improve post-merger efficiency. The wake of this proposal, discussions between the two companies advanced rapidly. On 8 November 1930, "after just two formal meetings, the intentions of both companies were in accord" and a tentative merger agreement was signed.

So what were the motives for this merger? First, one can point to the thorough rationalization of operations. The Osaka Mainichi Shimbun of November 9, 1930, carried a statement to the effect that "in light of the current Japanese financial situation, and the harsh realities of international competition, [Toyobo] and [Godobo], agreeing that a merger would serve the interests of improving efficiency of production, with the approval of the boards of both companies, have today signed a merger agreement" 25 (emphasis added). Additionally, Godobo, in an 
"explanatory guide" to employees, noting the worsening macroeconomic situation after the Great Depression and the intensification of competition with China, Southern Asia and America, in order not to "tread in the footsteps of Britain and face common financial failure" stressed the need "to unite boldly under a single management." 26 However, as far as I am aware, there are no primary sources describing such a concrete relationship between the merger and process of rationalization. I will return to this point in section four below when looking at the effects of the merger. Second, one can also point to a shortage of talent at Godobo. Following the death of former president Fusazo Taniguchi in April 1929, and the deteriorating health of his successor Akiyama, the company president at the time of the merger had been required to take on the role at short notice. Further, the Diamond economic newspaper noted that President Iio was "already elderly and, above all, not in good health. Moreover, there are no suitable candidates to take over the presidency of the company after Iio," and the issue of leadership succession at Godobo was cited as an "unmeasurable weakness." 27 Third, President Iio of Godobo suggested that the merger was in accordance with the wishes of former President Taniguchi, an advocate of the spinning company large-scale merger proposal. ${ }^{28}$ It is not possible to be certain of details due to constraints of materials, but the above three points appear to be the main motivations for the merger.

\section{Merger terms}

As touched upon earlier, the main factor hindering mergers in the spinning industry was asset valuation, that is, the difficulty of setting

25. "Gōdōbō Tōyōbō ni Gappei [Godobo to Merge with Toyobo]," Ōsaka Mainichi Shinbun, 9 November 1930.

26. Dairokushō Maruoka Ōsaka Gōdō Bōseki to no Gappei [Chapter 6-Maruoka The Merger with Osaka Godobo], Tōyō Bōseki 70nenshi—Kikōtei Rekishihen Ni, (Tōyō Bōseki Shashi Shiryō).

27. "Tōyō, Gōdōbō no Gappei to Zentō [The Merger and Future Prospects of Toyobo and Godobo]," Diamond, 21 November 1930 (below, "Gappei to Zentō"). Concerning this point, in the Shashi Shiryō [documents on company history] Katayama relates that "The immediate cause must have been that President Iio, weakened by asthma, was in a lonely position without anyone to rely on or trust" (Katayama interview).

28. Tōyō Bōseki Kabushiki Kaisha Shashi Henshūshitsu (ed.), Hyakunenshi Toyobo $J \bar{o}, 289$. 
acceptable merger terms. So how was that issue discussed in the Toyobo and Godobo merger process? Here, I attempt a multi-faceted approach by using the minutes of the Godobo shareholders meeting, considering the explanation of the company president (chairman) and the views of the company auditor, and additionally making use of media evaluation and the calculation of the merger ratio.

The merger conditions, in the tentative merger agreement, were (1) Toyobo would be the surviving company while Godobo would be dissolved, (2) merger ratio would be ten Godobo shares (at 50 yen paidup share capital) per seven Toyobo shares (at 50 yen paid-up share capital). Concerning item one, the dissolution of Godobo, the difference in the number of machine spindles between the two companies (1.97 million at Toyobo versus 490,000 at Godobo) was emphasized to shareholders, while to employees, "for procedural and many other reasons of convenience, it was decided to adopt the latter form" (not the establishment of a new company, but merger by absorption). ${ }^{29}$ The important point here is the process by which item two, the merger ratio, was decided. While the details remain unclear, the explanation provided by Godobo is as follows.

Document $1^{30}$

In short, in deciding the merger ratio, first and without doubt the most important point is the state of current assets; the second and a very important point is future earnings potential: that is, how much earnings or how much dividend can be expected in the future; these two are the most important in deciding the merger ratio. Another valuable point to take into consideration is earnings to date, and the ratio of past earnings to fixed assets; share price is also of course something to take into consideration, however, we ourselves are not keeping share price in mind.

From this document, we can see that assets, future profit and dividends, and efficiency of existing plant were considered important, while share price was not taken into consideration. This position was probably the result of the gap between stock price and valuation mentioned above. Using this measure, Godobo explained as follows

29. Dairokushō Maruoka Ōsaka Gōdō Bōseki to no Gappei; 72nd shareholder's meeting minutes.

30. 72nd shareholder's meeting minutes. 
what happens when the actual merger ratio is calculated. Concerning the evaluation of assets, Toyobo uncalled-up share capital of 1.5 million yen was a problem, with the concern being either to call up all capital immediately, or whether the capital "might not be available until some ten or fifteen years in the future." If the uncalled-up capital is also taken into account, the merger ratio of would be ten to 7.4, while if it was not included, the merger ratio would be ten to six. As Toyobo made no clear response on this matter, it is not known which figure was in fact considered more important. In the end, in addition to unpaid-up capital, "minute analysis" was carried out concerning plant location and the age of machinery and equipment, and taking into consideration "future dividend rate" and with "current profitability taken as the average of the last three years of earnings," the merger ratio was fixed. Finally, with the comment concerning the ten to seven ratio that "I honestly believe that there is no dissenting opinion in either company that this is not a truly fair solution," the tentative merger agreement was signed. ${ }^{31}$

There was no specific objection from shareholders concerning the merger ratio, and with the standard position towards the merger being that "a merger must be beneficial to both parties, as a merger which is beneficial to only one party can not be called a proper merger proposal; of course, in the current merger between [Godobo] and [Toyobo], concerning takeover, the boards of both companies have negotiated fairly for this merger, and I believe that it is beneficial to both parties" (statement by shareholder Furukawa Hiroshi), and the chairman emphasized that both companies would benefit from the merger. ${ }^{32}$ Thus, we can conjecture that the lack of shareholder objection was because either the merger ratio was fair, or it was beneficial to Godobo. However, the following statement by the auditor Mitani casts doubt on such speculation.

Document $2^{33}$

Considered from the perspective of [Godobo]'s assets, we cannot say

31. Furthermore, it is necessary to add the premium of the current market value to unpaid-up capital (72nd shareholder's meeting minutes).

32. This comes from the statement that "the common misperception is that [this deal] is greatly to the detriment of Toyobo and to the advantage of Godobo" (72nd shareholder's meeting minutes).

33. 72nd shareholder's meeting minutes. 
that the ratio of ten to seven is the best possible proposal...however the spinning industry situation changes in the future, it will continue to be in a chaotic state for a little while yet, and optimism about future prospects is not permissible. Observing a range of conditions, we approve with dissatisfaction this takeover, as it is better now to conclude this merger, from the perspective that it will provide some security regarding the future for us shareholders, and we agree to this takeover with feelings of regret and state that we wish this merger to go ahead" (emphasis added).

From this document, we can see that while dissatisfied with the merger ratio in terms of asset valuation, in order to deal with the uncertainty in the business environment surrounding the spinning industry, the auditor is of the opinion that in the current conditions it is preferable to accept the conditions and go ahead with the merger. In short, there are two perspectives on the merger: the chairman regards it as "fair" while the auditor regards it as disadvantageous to Godobo.

Going back to before the calculation, let's consider media reaction to the ten to seven merger ratio. First, Diamond ${ }^{34}$ regarded Toyobo as having the advantage. The evidence for this lies in the comparison of the net worth of each firm, calculated in the following way. Net worth is defined as the total of the real value of current assets plus the real value of current fixed assets; in the case of Toyobo this was 129,030,798 yen, and of Godobo 52,938,558 yen. From this is possible to calculate that the real market price of Toyobo shares (paid-up value 50 yen) was 175 yen, and of Godobo shares was 141 yen. Comparing these real market share values, if Toyobo is set at 100, Godobo would be 80.6 $(=141 \div 175)$, giving a merger ratio of ten to eight and indicating that the actual merger ratio is favorable to Toyobo.

The Ekonomisuto evaluated the merger as being "perhaps slightly in Toyobo's favor." As the Ekonomisuto did not make close calculations like Diamond we can omit details, but they based their analysis on the following evidence: (1) when viewed superficially from fixed assets per spindle, Godobo's asset quality appears the better (Toyobo 45 yen 60 sen, Godobo 34 yen 50 sen), but Toyobo's machinery and equipment were superior; (2) when viewed from the perspective of daily cotton

34. The following description is from "Gappei to Zentō," Diamond, 21 November 1930. 
production per spindle, while Godobo produces more (Toyobo 72.8 monme [273g], Godobo 80.6 monme [302.25g]), Toyobo had relatively low production costs; and (3) the ratio of external debt to total assets excluding uncalled-up capital was higher for Godobo (Toyobo 14\%, Godobo 19\%), and the content of that debt was inferior. By examining not only superficial figures, but also machinery and production costs, coupled with qualitative aspects such as the content of liabilities, we can say that it was a comprehensive evaluation. ${ }^{35}$

As mentioned above, the actual merger terms were reported to be to the advantage of Toyobo, Godobo's auditor having a similar opinion. Therefore, let us repeat an analysis of the merger ratio to establish whether the evaluation at the time was reasonable. ${ }^{36}$

The merger ratio is calculated as follows. Using the market value method the ratio would be 1:1.07, using the income approach method $1: 0.90$, and using the means methods $1: 0.98 ;{ }^{37}$ whichever method is used, it is clear that the actual merger ratio is marginally in favor of Toyobo. However, using profit after depreciation the ratio calculated from the income approach becomes $1: 0.71,{ }^{38}$ which closely matches the actual ratio; consequently, it cannot be said that the ratio was entirely in Toyobo's favor. Here, let us establish the evidence for Iio's opinion that the merger ratio was calculated "fairly." Nevertheless, the fact stands out that the result was unfavorable for Godobo. What then is the reason that the management and shareholders of both companies accepted those merger conditions (although there were some reservations expressed)? I have already raised this point earlier (referring to Godobo's personnel issues and obsolete equipment), but here I wish to touch on the issue of trade unions.

As is well-known, after World War I, Japan's labor movement developed in earnest, and labor disputes in the spinning industry peaked in the years 1929 and 1930. In May 1927 at Godobo's Kanzaki factory,

35. "Gappei," Ekonomisuto, 1 December 1930.

36. Methods of calculating the merger ratio were (1) income approach method, (2) market value method, (3) the average of the income approach and the market value methods.

37. The share value per share and the net capital per share were respectively 249 yen and 106 yen for Godobo, and 277 yen and 100 yen for Toyobo.

38. In this case, share value per share becomes 170 yen for Godobo and 241 yen for Toyobo. 
400 employees took part in a strike protesting against layoffs. ${ }^{39}$ The media reported that at the company's Osaka plants (Tenma, Imamiya, Sumiyoshi, and Kanzaki) "the influence of labor unions is increasing. For this reason, today there are many superfluous workers, and performance is stagnating," 40 and "trades unions have established extremely solid foundations, causing a certain feeling of unease in management, and the company will have to take action some time." ${ }^{\prime 1}$ Godobo, then, had problems with staff not just at the board level, which would have been a factor weakening the company's bargaining power over merger conditions.

So far I have considered the merger ratio as calculated from assets and profitability, taking into account Godobo's management resources, but this alone cannot explain the reaction of the company's shareholders mentioned above. If we consider the merger ratio from the perspective of the companies' share prices in 1930, Toyobo traded at an average price of 143.7 yen (maximum 182.9 yen, minimum 104.5 yen), while Godobo traded at an average price of 94.6 yen (maximum 129.5 yen, minimum 59.7 yen), ${ }^{42}$ from which we can derive a merger ratio of 1:0.66. Considered in the light of this value, the actual ratio can be seen to be slightly advantageous to Godobo, and also explains the lack of shareholder objection. At the same time, we can understand why the management of Godobo, emphasizing the gap between assets and share price, determined the merger ratio without regard to the latter. ${ }^{43}$

With the launch of the new "Dai-Toyobo," the management of the former Toyobo continued in exactly the same form, under President Abe Fusajiro, Vice President Shoji Otokichi, and Managing Directors Kenzo Taneda and Keizo Seki, and the board of Godobo resigned en masse. Given Godobo's noted personnel issues it could be said that this was an appropriate choice, however, we can also see that the company was

39. Kajinishi, Gendai Nihon Sangyō Hattatsu Shi, 448-449.

40. "Gappei to Zentō," Diamond, 21 November 1930.

41. "Gappei," Ekonomisuto, 1 December 1930.

42. Osaka Yashōten Chōsabu, Kabushiki Nenkan [Stock Yearbook], 1931.

43. Of course, when considering share value, Godobo was likely to find itself facing stringent conditions. On the other hand, from the perspective of Toyobo shareholders, their shares were being undervalued, and consequently might express their dissent at the shareholders' general meeting or on other occasions. However, documentary limitations mean that there are no details on this point. 
forced to make drastic concessions concerning board members during the merger negotiations. ${ }^{44}$

\section{Effects of the merger: resource reallocation}

As mentioned earlier, the merger of Toyobo and Godobo was realized as a response to fierce international competition, and aimed to ensure operational rationalization. However, as far as I am able to ascertain, there is no documentary evidence of the expectations that the parties had of the effect of the merger. Media however reports provide a means of approaching this point.

First, it was pointed out that "cost savings through administrative simplification, mass production and cost reductions possible because of unification of general operations, and profits arising from the simplification of conflicting brands" 45 could be expected. While lacking in detail, "administrative simplification" refers to the integration of noncore businesses and the resulting staff reductions; "unification of general operations" refers to cutting production in accordance with the agreement to curtail production by mothballing inefficient factories and focusing production in efficient factories; and "simplification of conflicting brands" probably refers to product reorganization.

Second, and on a related note, the complementarity of plant and main business locations was cited as a benefit of the merger. That is, while Toyobo's main production bases were in the Chukyo area (Nagoya and surrounding areas) including Yokkaichi, Tsu, Aichi, Owari, Nagoya, Chita, and Hamamatsu, and in which "same areas [Toyobo] also had particularly strong sales," Godobo's plants were in Imamiya and Tenma in Osaka city and the surrounding area, Komatsujima in the Seto Inland Sea, Imabari, Ako, and Fuchizaki. Additionally, while many of Godobo's customers were to the west of the Kansai area and its "brand was well regarded" in that region, it had no factories in the Chukyo area and was not able to fully develop that market. In short, while there was little overlap in production and sales areas, it was noted that "savings

44. From the May 1931 structure of the board of directors. Additionally, at first, the conditions required that Director Yamaguchi from Godobo was retained as a board member and President Iio as an advisor to the board (Katayama interview).

45. "Daitōyōbō no Naiyō [Details of Dai-Toyobo]," Tōyō Keizai Shinpō, 22 November 1930. 
arising from exchange of suppliers are likely to be relatively small. However, there is no small benefit from extending influence in all regions." 46

Third, a complementary relationship was observed for the companies' products. While Toyobo produced a full range of cotton yarn including thick, medium and thin threads, Godobo did not produce any thin cotton thread. Looking at the distribution of cotton products, thick yarn (including No. 20 count yarn) was a core product for both companies, accounting for nearly 70 percent of their production. However, while 38 percent of Toyobo's cotton yarn production for fabric weaving was mostly coarse thread of less than No. 20 count, in Godobo's case that was no more than 16 percent, most of which was medium-weight yarn. Therefore, of yarn sold, Toyobo increased its product weighting into No. 20 count and medium weight yarns, while Godobo increased the ratio of coarse yarns produced. ${ }^{47}$ That is, when comparing each company's products taking into account purpose, their cotton products were not necessarily in competition. Next, looking at woven fabric, while 93 percent of Godobo's production was calico (4.683 million yards), Toyobo's production was far more diversified, comprising coarse cloth (5.337 million yards, 38 percent of production), high-weight calico (4.326 million yards, 30 percent), cotton twill (2.056 million yards, 14 percent) and fine cloth (196 yards million, 13 percent). ${ }^{48}$

As described above, the effects of the merger of Toyobo and Godobo went beyond management rationalization. Advantages including complementarities in factory locations, sales areas and products were highlighted. However, documentary constraints mean that it is difficult to prove this empirically. So, I would like to focus on the effects of the merger on the plant of the former Godobo, and how Toyobo implemented the redistribution of resources after the merger.

46. Additionally, the reason that Godobo chose the coast of the Seto Inland Sea as the site of its new factory were as follows: (1) the availability of water transportation allowed large carrying capacity and reduced transportation costs; (2) "there were few causes of labor disturbance, and it would be easy to prevent the spread of disturbances from other areas"; (3) temperature and humidity changes were relatively less than other areas (“Gappei to Zentō," Diamond, 21 November 1930; Katayama interview).

47. "Gappei to Zentō," Diamond, 21 November 1930.

48. “Gappei," Ekonomisuto, 1 December 1930. 
As mentioned earlier, most of Godobo's machinery was outdated, and except for the cutting-edge Kanzaki plant much of it was in need of improvements and repair. Notably, from 1932 onwards, Toyobo implemented a policy of maintaining the quality of its own factories from before the merger, while shifting the focus of new investment to the factories of the former Godobo. For example, at the Nomi factory, the company attempted to develop a "regional factory" by increasing the number of spindles by more than 16,500 spindles to over 32,600 spindles. In factories in Tenma, Hiroshima and Sumiyoshi, facilities were improved and extended. At the Kanzaki factory mentioned above, "over 6,600 spindles were moved to other factories as a result of facility adjustment, adding over 5,200 spindles to the Komatsushima factory." 49 In addition, construction started in 1932 on two factories planned by the former Godobo at Sanbonmatsu (66,200 square meters) and at Fuchizaki (99,300 square meters), both in Kagawa Prefecture. The factories were completed and began operation in the first half of 1933. At Sanbonmatsu, fine spinning machines (designed for coarse No. 14-15 count yarn) with 25,200 spindles were installed, and at Fuchizaki the same machines (designed for No. 30 count medium yarn) with 36,000 spindles were installed. In particular, at the Fuchizaki factory, aiming to install advanced overseas machinery in a temperature- and humiditycontrolled environment, "British-made spinning machines were installed in a flat-roofed concrete building with window-lighting." Meanwhile, the Sanbonmatsu factory was of "traditional architecture," and housed the latest model of domestically-produced Toyoda Automatic Loom Works, Ltd. spinning machines. These plans were implemented with the intention of "carrying out an active attempt at a comparative study of current cutting-edge technologies." Construction cost per spindle at both plants was 130 yen (the Ichinomiya factory was 70 yen), a fairly expensive investment compared to the aforementioned figures of 75 yen for Toyobo and 65 yen for Godobo (Sanbonmatsu 25,200 spindles $\times 130$ yen $=3.276$ million yen, Fuchizaki 36,000 spindles $\times 130$ yen $=4.68$ million yen). ${ }^{50}$

49. Additionally, while the number of spindles at the Imamiya factory was increased, "the equipment was old and of small scale, and the environment was poor," in July 1937 the factory was closed (Tōyō Bōseki 70nenshi Henshū Iinkai, Toyo Bōseki 70nenshi, 279-280). 
We cannot rule out the possibility that Godobo could have completed the above investments by itself, but it is possible that its completion in a effective fashion was facilitated by the merger with Toyobo. ${ }^{51}$ At the least, the financial issues pointed out by Diamond were successfully overcome, that is, other than the Ako plant, "it is not possible to say exactly how much would be required for machinery and equipment improvements, but in order to reorganize on the same lines as Toyobo would require a vast investment." 52

Next, I would like to focus on how Toyobo management methods were adopted in the factories of the former Godobo. That is, Godobo's branch system was converted to Toyobo's factory system, and "representatives of [Toyobo] that had been dispatched to each factory were made managers of those factories." 53 The difference between these systems had the result that "Godobo measured performance on a perbranch basis, and so consequently failed to reach the level of Toyobo on production-per-spindle." Taking a slightly more concrete example, in Godobo's case "for example, if the Tenma plant produced 75 monme per spindle $(281.25 \mathrm{~g})$ and the Kanzaki plant managed 80 monme per spindle $(300 \mathrm{~g})$, these values were set as the 100 percent baseline for each and variations were discussed. Through setting this 100 percent standard for each factory, Toyobo discussed the relative merits of performance of each. Godobo was falling behind on these points, so a policy of ignoring local conditions was taken and the Toyobo system of per-spindle production quantity or cost accounting was implemented across all factories. On technical aspects, as Toyobo was certainly slightly more advanced, the Toyobo system was adopted" (emphasis added). Also, "Toyobo was a pioneer in refining standardized working processes, leading other companies. Kanebo is being talked up by people, but in reality is not much to write home about. The administration of Godobo

50. The decision to construct these two factories was given at the end of 1931, responding to the "ardent invitation of the related towns and villages" (Tōyō Bōseki Kabushiki Kaisha Shashi Henshūshitsu ed., Hyakunenshi Toyobo Jō, 290-291, 305-306).

51. To confirm this point it is necessary to compare with the original planned completion date and budget, but this is not possible due to lack of documentation.

52. "Gappei to Zentō," Diamond, 21 November 1930.

53. This indicates that the transfer of human resources from Toyobo to Godobo prior to the merger also resulted in the transfer of factory management techniques (Tôyō Bōseki 70nenshi Henshū Iinkai, Toyo Bōseki 70nenshi, 271). 
was in comparison in no way inferior to that of other companies, but the common feeling of the staff was that we wanted to take into account the technological advantages of Toyobo" (emphasis added). ${ }^{54}$ The above evidence can be interpreted as showing that the "refined" personnel and factory management and evaluation techniques and knowhow of Toyobo were redistributed to the factories of the former Godobo.

\section{CONCLUSION}

So far I have examined the motivations for, conditions and effects of the merger of Toyobo and Godobo during the Showa Depression. The results of this analysis can be summarized as follows.

The merger of Toyobo and Godobo was realized only after the collapse of the proposed large-scale merger of four of the five big spinning companies. The motivations were unmistakable: against the macroeconomic background of the Showa Depression and the lifting of the gold embargo, and the intensification of international competition, both government and industry were demanding thorough industrial rationalization. On this point it is possible to see commonalities with other large mergers carried out in the early 1930s such as those resulting in Oji Paper and the Nippon Steel Corporation. At the same time, the large merger proposal, sunk by problems over asset valuation, bore great similarity to problems faced by heavy industry and the heavy electric industry.

Next, while the shareholders of Godobo, the company being taken over, did not raise strong objections, the company's auditor did express the opinion that it was disadvantageous to Godobo. On the other hand, Godobo's President Iio, when calculating the merger ratio, did not refer to share price, rather focusing on assets, future profits and dividends, and plant efficiency, stressing that "fair conditions" had been drawn up. Additionally, the media evaluated this merger ratio as being advantageous to Toyobo. Except for some few measurements, most figures calculated in this paper supported the claims of the Godobo auditor and the media. In other words, we can conclude that the actual merger ratio was favorable to Toyobo. Importantly, Godobo had several

54. Katayama interview. 
problems including company performance and debt configuration, management, and labor unions. Therefore, the company did not hold a strong bargaining position, and it is probable that it was forced to make concessions over the merger conditions. In other words, with the low quality of Godobo's management resources acting as a discount, we can conclude that "fair conditions" for the merger were set. On the other hand, when considering figures based on the stock price of the company, the merger conditions appear slightly favorable to Godobo, and this is the probable reason for the lack of objection from shareholders.

Finally, after the merger, Toyobo unified operations at the factories of the former Godobo under the "Toyobo system" and implemented more efficient operating procedures, and from 1932 shifted focus to expand and modernize the former Godobo factories, and began construction on the planned factories at Sanbonmatsu and Fuchizaki. Cutting-edge technology was introduced at these factories, and investment in construction was far greater than in other factories. It appears that the construction proceeded relatively smoothly as the leaders of the construction project transitioned to the financially wealthy Toyobo.

Among the above facts we can see that, after the merger, Toyobo did not find it difficult to redistribute resources to Godobo factories. This redistribution did not stop just with the replacement of the factory manager (personnel), but through a wide range of factors including factory operations and performance evaluation methods (information), funds for focused investment in improving plant (money), and through this broad redistribution attempted the efficient employment of the assets acquired from Godobo. Such a unilateral reallocation hints at the inferiority of the Godobo management in comparison to Toyobo. Hence, the validity of the stringent merger conditions set upon Godobo is apparent; in other words, if the company's management situation is considered, we can conclude that the merger conditions were indeed fair.

Note

This paper is based on research funded by a Japan Society for the Promotion of Science Research Grant (Young Scientists [B]). 